\title{
Changes in ethnic spatial segregation across English housing market areas (2001-2011): identifying ethnic and context configurations
}

\author{
La segregación étnica en Inglaterra a través del tiempo (2001-2011): \\ un estudio comparativo de ocho áreas habitacionales
}

\author{
Carolina V. Zuccotti ${ }^{1}$
}

\begin{abstract}
Using a combination of segregation indices - calculated with aggregated census data obtained for small geographies (lower layer super output areas, LSOAs) - the paper shows levels and changes in spatial segregation in eight housing market areas (HMAs) in England between 2001 and 2011, for the six most numerous non-white ethnic minority groups (Indian, Pakistani, Bangladeshi, Chinese, Caribbean, and African). The double comparison between HMAs and between groups, together with the use of different measures of segregation, enables identifying different patterns of segregation, as well as 'ethnic' and 'context' configurations. Specifically, while some segregation patterns are distinctive to certain ethnic minority groups independently of their location, others are specific to some or most groups residing in certain contexts. As examples of the first, Pakistanis and Bangladeshis' segregation levels are often the highest, independently of their HMA of residence; and also seem to be following specific (and contrasting) patterns of change over time. As regards context configurations, Birmingham appears as a favourable context for changes in spatial segregation, while the opposite is observed for Leicester and Bradford.
\end{abstract}

Keywords: England; ethnic groups; housing market areas; spatial segregation.

\section{Resumen}

A partir del análisis de índices de segregación espacial—calculados a partir de datos censales agregados obtenidos para pequeñas áreas geográficas (lower layer super output areas, LSOAs) —el estudio muestra niveles y cambios en la segregación espacial (2001-2011) de las principales minorías étnicas en Inglaterra (indios, pakistaníes, bangladesíes, chinos, caribeños y africanos), para ocho áreas habitacionales (HMA). La doble comparación entre HMA y entre grupos, junto con el uso de variados índices de segregación, permite identificar diferentes patrones de segregación espacial, así como dinámicas 'étnicas' y 'de contexto'. Específicamente, mientras que algunos patrones de segregación son distintivos de ciertos grupos étnicos (independientemente de su área habitacional), otros son específicos de ciertas áreas. Como ejemplos del primero, los niveles de segregación de paquistaníes y bangladesíes son a menudo los más altos, independientemente de su HMA de residencia; también parecen seguir patrones de cambio específicos (y contrastantes) a lo largo del tiempo. En cuanto a la dinámica del contexto, Birmingham aparece como un contexto favorable en términos cambios en los niveles de segregación, mientras que se observa lo contrario para Leicester y Bradford.

Palabras clave: Áreas habitacionales; Inglaterra; grupos étnicos; segregación espacial.

1 Consejo Nacional de Investigaciones Científicas y Técnicas, Universidad de San Andrés, Argentina. Carolina.zuccotti@alumni.eui.eu 


\section{Introduction}

\subsection{Motivation and aims}

The spatial segregation of ethnic minorities is a well-established phenomenon in many countries in Europe (Müller, Grund \& Koskinen, 2018; Musterd \& van Kempen, 2009; Parreño Castellano \& Domínguez Mujica, 2008) and elsewhere around the world (Ariza \& Solís, 2009; Logan, 2013). Much of the research on this topic has been devoted to studying whether this is decreasing over time or not. A reduction in ethnic spatial segregation is often a desirable outcome, since segregation might be an impediment to social cohesion (Sturgis, Brunton-Smith, Kuha, \& Jackson, 2014; Uslaner, 2012). Also, there is evidence of its potential negative effect on a series of outcomes, such as those associated to labour market opportunities (e.g. Yang, Zhao \& Song, 2017; Zuccotti \& Platt, 2017). In the UK, research on trends of ethnic spatial segregation is vast, and has been based on different methodologies. ${ }^{2}$ In general there is an agreement that ethnic minorities are dispersing in space and that ethnically mixed areas are on the rise; at the same time, this is often also coupled with the creation of areas where white British individuals constitute a minority. Less is known, however, about how ethnic segregation looks like in different parts of the country. This study aims at filling in this gap. Using unevenness, exposure, concentration and clustering indices to measure segregation, the paper shows levels and changes (2001-2011) in spatial segregation for the six most numerous non-white ethnic minority groups (Indian, Pakistani, Bangladeshi, Chinese, Caribbean and African) in eight empirically defined English "housing market areas" (HMAs) (Jones, Coombes \& Wong, 2010). The double comparison between HMAs and between ethnic groups allows identifying not only whether some groups' segregation patterns occur independently of their location (what I call ethnic configurations), but also whether some (or most) groups' segregation patterns have specific characteristics in certain contexts (what I call context configurations). The study provides, therefore, a strong comparative perspective to the analysis of segregation. Rather than focusing on whether segregation is increasing or decreasing, it is centred on how comparisons can help shed light on ethnic and context configurations associated to segregation.

The article is organized as follows. The next sub-section introduces the UK context and previous studies. Section 2 describes the methodology. Section 3 presents the results: first I provide an introductory overview of non-white segregation patterns across HMAs; then I move to the core of the analysis, and present the results of levels and changes in segregation for all ethnic minority groups in the eight selected HMAs. Sections 4 and 5, finally, discuss the results and conclude.

\subsection{Ethnic segregation in the UK: context and previous studies}

The arrival of non-white ethnic minorities in the UK initiated in the late 1940s, in the context of the economic recovery after the Second World War. Caribbeans where the first to arrive; these were followed by Indians and Pakistanis, while the remaining three groups arrived majorly in the 70s. The initial pull of immigration to the UK was mainly economic (Panayi, 2010). Upon arrival, most ethnic minorities established themselves in the north and central areas of the UK, following industrial expansion and the subsequent creation of jobs after the Second World War. This location was mainly in metropolitan areas (Simpson \& Finney, 2009); London, in particular, was the main point of attraction (especially for Caribbean, Africans and Bangladeshis), followed by urban areas in the East and West Midlands (Birmingham and Leicester), North West (Great Manchester) and Yorkshire and the Humber (Bradford and Leeds), where a higher number of Indians and Pakistanis live. These continue to be the main locations of nonwhite ethnic minorities.

Although the spatial segregation of ethnic minorities has gained importance in policy debates after the 2001 riots in the north of England (Bagguley \& Hussain, 2019), it is a phenomenon rooted in the history of ethnic minorities' settlement in the UK. The initial location of most non-white immigrants in metropolitan areas was often marked by poverty and hostility (Phillips, 1998; Rattansi, 2011). Immigrants resided either in poor private accommodations or in the worst of owner-occupied houses; and the

2 Some studies (Catney, 2017; Simpson, 2012) use segregation indices, with the dissimilarity index (Duncan \& Duncan, 1955) being the most commonly used. Other studies treat spatial segregation by creating different 'ideal types' of areas, with varied relative shares of ethnic minorities (Johnston, Poulsen \& Forrest, 2010, 2015). A more recent group of studies have started to advance new methods for studying segregation, also based on indices, but with greater attention to geographical scales and the interrelations between them (Johnston, Jones, Manley, \& Owen, 2016; Jones, Johnston, Manley, Owen, \& Charlton, 2015). 
same apply to public housing, to which they gained access in the mid-1960s. Spatial segregation based on ethnicity started therefore to emerge as a problem, and this was reinforced by white suburbanization. Moreover, the link between race and deprivation became evident, not only in terms of public perception, but also as a factor that would generate a legacy of disadvantage in the years to come. Many minorities were found to be trapped in marginal areas in regions of industrial decline, which would later on affect their opportunities in terms of employment and housing (Phillips, 1998).

Studies based on segregation indices (e.g. Catney, 2017, 2018; Simpson, 2007; Simpson, 2012) show that segregation levels vary considerably depending on the ethnic group, geographical scale and segregation index used. The most recent estimations (based on 2011 Census) show that Pakistanis and Bangladeshis are among the most segregated non-white groups, in several dimensions of segregation and also at different geographical scales. On the other hand, Black Africans and Caribbeans have in general lower segregation levels, especially when this is measured using smaller geographical units (Johnston et al., 2016; Jones et al., 2015). Over time, segregation measured with the dissimilarity index has tended to decrease for all groups, especially between 2001 and 2011, both at the national level and in most local authorities, ${ }^{3}$ including those in the largest metropolitan areas (Catney, 2013, 2016b). In fact, ethnic minorities are becoming more evenly distributed and are moving to the suburbs of London (Catney, 2016b, 2017). There is also evidence that ethnically diverse areas, as well as the number of ethnic minorities residing in areas that were typically white, are increasing (Catney, 2016a), especially in London (Johnston, Poulsen \& Forrest, 2015). In particular, the decrease of segregation in London is observed at the micro-scale, rather than at the macro-scale (Johnston et al., 2016). Greater dispersion is likely to follow from general processes of social and spatial integration (Alba \& Nee, 2003; Massey, 1985), and from an increasing role of governments in this. In the UK, ethnic minorities, in particular the second generations, are increasingly obtaining better educational and labour market outcomes (Cheung $\&$ Heath, 2007; Crawford \& Greaves, 2015). These assets allow them to more easily move to areas with fewer members of their own ethnic group, as recent research shows (Coulter \& Clark, 2018; Zuccotti, 2019). At the same time, the 1967 Race Relations Racial Acts, and several amendments that followed, have helped tackle discrimination in various domains, including the housing market.

Parallel to these developments, exposure to co-ethnics in the neighbourhood has tended to increase for most groups; the same is observed for clustering indices (Catney, 2017), which measure the extent to which ethnic minorities live in neighbourhoods that adjoin. This has been confirmed by other studies, which have investigated the spatial segregation of ethnic minorities using a typology of areas - wherein Type 1 includes areas where whites predominate, and Types 4 to 6 include areas where the non-whites predominate. These studies have shown that for the period 1991-2001 all ethnic groups are more likely to reside in areas with a higher ethnic concentration (Poulsen \& Johnston, 2008), including those where one ethnic group constitutes a majority (Types 5-6). Similar findings were found for the city of London for the period 2001-2011 (althuogh there is no increase in areas where only one group predominates; see: Johnston, Poulsen \& Forrest, 2015). Harris, Johnston and Manley (2017) also show that, on average, exposure between ethnic minority groups has increased, while exposure between ethnic minority groups and white British individuals has decreased. One the one hand, these developments are an inescapable outcome of demographic change: ethnic minorities are increasing their share of the population, both through net migration and though higher birth rates (Finney \& Simpson, 2009a). ${ }^{5}$ On the other, they might also point to other mechanisms such as preference for proximity to co-ethnics and discrimination in the housing market or harassment (Johnston, Poulsen \& Forrest, 2015; Schaake, Burgers \& Mulder, 2013). In the UK, there is evidence of both mechanisms taking place (Bowes, Dar \& Sim, 2002; Phillips, 2006), especially for Pakistanis and Bangladeshis. Studies based on longitudinal individual-level data (Coulter \& Clark, 2018; Zuccotti, 2019) also show evidence of ethnic penalties in neighbourhood attainment. Overall, even if dispersion exists (especially among those with more socioeconomic resources), ethnic minorities are still on average more likely to reside in ethnically concentrated (and deprived) areas; this applies to individuals raised in the UK too.

3 Administrative units, with an average of 135,000 individuals.

4 Micro-scale is the small area scale (in this case, Output Areas, which comprise around 500 individuals on average). Using a multilevel framework, the article shows that segregation has decreased when measured with these small areas, and after the effect of the macroscale (i.e. larger areas that include the small areas) has been removed.

5 According to Census data, in 2011 around 12 percent (more than six million) of individuals living in the UK had an Asian or a black Caribbean/African self-declared ethnicity (among these, circa 40 percent were UK-born individuals). This represents a great increase compared to 1971, when the population of non-white ethnic minorities (mostly foreign-born) was 2.3 percent (a bit more than one million). 
The present study adds a comparative, and complementary, perspective to the analysis of segregation. Rather than focusing on whether segregation is increasing or decreasing, it exploits the comparison of different housing market areas in which most ethnic minorities reside - and to which they are also "spatially bounded" (which is the nature of the definition of the housing market itself) - to study segregation patterns. As shown later on, this perspective allows showing that while some segregation patterns are very much dependent on the ethnic group itself, others seem to occur only in certain contexts or for particular groups in certain contexts.

\section{Methodology}

The analysis is based on segregation indices that measure different dimensions of segregation, calculated for the most numerous ethnic groups (Indian, Pakistani, Bangladeshi, Chinese, Caribbean and African) residing in eight housing market areas. Furthermore, I also explore indices for a category of (pooled) non-whites, which includes all previous ethnic minority groups plus other (self-defined) nonwhite individuals. Non-British white individuals and mixed-white individuals (in total around $8 \%$ of the total population in England 2011) are excluded from the analysis. Data comes from the census of England (2001-2011), and is obtained for lower-layer super output areas (LSOAs). ${ }^{6}$

To aid the interpretation of results, and given the high number of indices obtained (five indices for six ethnic minority groups in eight housing market areas), the information is summarized with cluster analysis (Ward connection method), where the units of analysis are ethnic groups in HMAs (48 in total). Cluster analysis allows grouping the 48 units of analysis in clusters-based on the information provided by the five indices ${ }^{7}$-and hence identifying different segregation patterns across ethnic groups.

\subsection{Selection of areas}

Segregation indices measure the distribution of individuals across geographical units (e.g. census tracts) within a larger area (e.g. countries, regions or metropolitan areas). For this study I use LSOAs ${ }^{8}$ as geographical units, which have an average of 1,500 individuals, and can be thought of as "neighbourhoods' in which individuals reside. LSOAs vary in terms of size: highly densely populated areas (e.g. areas with around 400 persons per hectare) might include a few blocks, while less dense areas (e.g. areas with around 100 persons per hectare) might include 8-10 blocks. For each LSOA I have collected information on the number of individuals from each ethnic group, using the question on ethnic self-identification. ${ }^{9}$

Segregation indices are calculated for eight housing market areas, a geographical classification created through a project commissioned by the National Housing and Planning Advisory Unit. HMAs are the result of analysing three types of information: commuting, migration and housing prices (Jones, Coombes \& Wong, 2010). Technically speaking, the system of local housing markets can be seen as series of tiers, where the roles of journey to work, household migration and housing prices are fundamental. The authors of the HMA classification divide between framework housing markets (upper tier) and local housing markets (lower tier).

A tiered approach to policy sees the framework housing market area as providing the long term horizon for strategic planning encompassing projected household changes, transport connectivities, housing land availability, housing market change, urban capacity study and addressing major initia-

6 Census data was obtained from https://www.ons.gov.uk/census and was geo-referenced with the help of an open-source software, Quantum GIS (http://www.qgis.org/en/site/index.html). This program was also used to create the maps. The digital vector boundaries for LSOAs and Local Authorities, to which I have attached census data, were obtained from the Open Geography Portal of the Office for National Statistics (https://geoportal.statistics.gov.uk/geoportal/catalog/main/home.page).

7 Indices were standardized before performing the cluster analysis.

8 Analyses were done separately for each year. Some LSOAs were split/merged between the two time points. A total of 72 LSOAs from 2011 were dropped, given that they changed shape between both years, and they did not match HMAs (based on 2001 geographies). I have also replicated the results erasing all LSOAs that suffered a change between 2001 and 2011, and the results remain the same.

9 It has been largely acknowledged by the literature that the selection of one or another geographical unit might impact on the conclusions we reach (Openshaw, 1984). However, in the UK, there is evidence that the relative position of ethnic minority groups in terms of their segregation levels usually remains the same when using geographical units that are relatively small (Simpson, 2007) (especially as regards the higher segregation of Pakistanis and Bangladeshis). This has also been shown, for London, in research using a more complex methodology (Johnston et al., 2016). Also note that, generally, it is accepted that segregation measured with smaller geographical units leads to higher levels of segregation (Yao, Wong, Bailey, \& Minton, 2018). However, a recent study for London (Jones et al., 2015) that measures segregation using a multilevel framework, shows that segregation measured with LSOAs tends to lead to lower segregation levels, on average, compared higher-level census geographies. We do not know if this is the case for other parts of the country. 
tives like growth areas. The local housing market area can be seen as the short term perspective in which planning also has to operate. (Jones, Coombes \& Wong, 2010, pp. 34)

The study uses the framework housing market area (upper tier). This divides the country into 75 HMAs (Jones, Coombes \& Wong, 2010). The upper tier framework is specifically defined by long distance commuting flows with a high level of commuting closure (areas within which $77.5 \%$ of people live and work) and the long term spatial framework with which housing markets operate. The importance of using HMAs to study segregation (rather than other geography like cities or local authorities) is that within housing markets one can assume that people's choice of location for a new residence is more or less 'constrained': in other words, residential moves are assumed to happen mostly within housing markets (and not between them). This is good for segregation studies because it implies that any increases in segregation connected to residential movements are likely to be promoted (at least in part) by ethnic groups (be these white British or a minority) preferring to live next to co-ethnics and/or, in the case of ethnic minorities, deciding to do so due to external factors such as harassment or discrimination. More generally, adopting these areas for both urban planning and segregation analyses can also proof useful for developing policies that aim to promote equal access to the urban space for all.

Out of the 75 HMAs, I selected the eight with the highest number of non-white ethnic minorities (comprising, in total, 80 percent of non-white ethnic minorities). These also follow the main metropolitan areas. The housing market area with the highest number of non-white ethnic minorities is London, followed by Manchester. Other HMAs are: Luton \& Milton Keynes and Reading (next to London); Birmingham and Leicester in West Midlands; and Bradford and Leeds in West Yorkshire (see Figure 1). London is the biggest and most populated HMA, and the one with the highest number of small and highly dense LSOAs; around 70 percent of LSOAs have a land area below the median and a population density above the median. Following London, Manchester and Birmingham have around 60 percent of highly dense and small LSOAs. Leeds, Leicester and Reading, in contrast, have the lowest number of small and dense LSOAs (see Table A1 in the Annex). Tables A2 and A3 contain information on the distribution of groups across and within HMAs.

Figure 1. Selected housing market areas. Local authorities in England

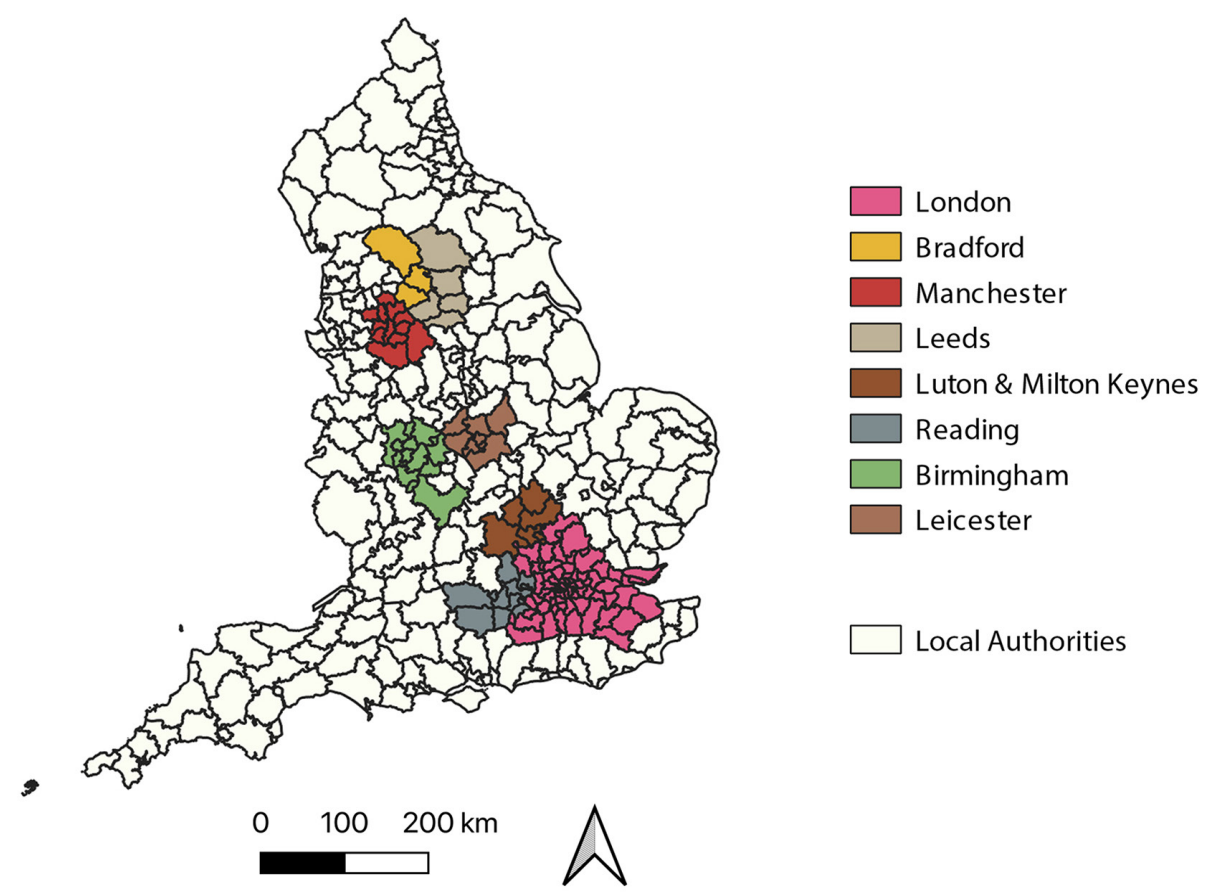

Source: 2011 UK Census. Local Authority boundaries. Own Elaboration

\subsection{Segregation indices used in this study}

This study explores four dimensions of ethnic segregation, unevenness, exposure, concentration and clustering, which are measured with five indices (Iceland, Weinberg \& Steinmetz, 2002; Massey \& Den- 
ton, 1988; Sørensen, Taeuber \& Hollingsworth, 1975). To measure evenness I use the dissimilarity index (IS), which measures the distribution of a group across all units (LSOAs) within a larger area (HMA). This index, whose calculation is done with respect to white British individuals (see also Jargowsky, 2018), can be interpreted as the proportion of a certain (minority) group that would need to change their LSOA in order to achieve a distribution equal to that of white Britons in the HMA. The dimension of exposure refers to the degree of potential contact between individuals in the same LSOA. The basic assumption is that by virtue of living in the same neighbourhood, individuals are physically exposed to one another. These indices have been interpreted in terms of "experienced segregation" (Massey \& Denton, 1988). There are two main indices within this dimension: the Isolation Index (xPx) and the Interaction Index (xPy). The first is used to measure the exposure between individuals of the same group, while the second measures exposure between a certain ethnic minority group and white Britons. These indices are sensitive to the relative sizes of the groups. If the group being compared is relatively large within a certain area, then the likelihood that their members will meet someone of the same group is greater (and the likelihood that they will meet someone from another group is smaller). Conversely, if the group is small, their members have a greater likelihood of meeting people from the majority/comparison group. A group might therefore be unevenly distributed, but at the same time, be very likely to meet people from the majoritarian or other groups if its number of members is small. Isolation and interaction indices are affected by population growth: an increase of members of a minority group is likely to lead to an increase in $\mathrm{xPx}$ for that group, and a decrease in xPy with respect to the white British. Both the isolation and interaction indices vary between 0 and 1 and can be interpreted as the likelihood of sharing the same area with an individual of the same or different group. ${ }^{10}$

The dimension of concentration expresses the degree to which a group occupies a small share of a wider geographical area. In practice, this means that such group is mainly located in the smaller neighbourhoods (in this case, LSOAs). I measure concentration with the Relative Concentration Index (RCO), which measures the concentration of a group relative to a second group (white British individuals). The Index varies between -1 and 1 , where a score of 1 means that the concentration of the group exceeds that of the white British group to the maximum extent possible; -1 means the converse; and 0 means that both groups are equally concentrated in the urban space. This index takes into consideration the shape and size of LSOAs (although not their relative position in the wider area). Clustering, finally, refers to the degree to which area units inhabited by certain social groups adjoin one another, or cluster, in the space. The more clustered the areas are, the higher the segregation will be. These indices take therefore into consideration the relative location of the LSOAs in the space; specifically, they measure the extent to which LSOAs where a certain ethnic minority group lives are contiguous. Within the dimension of clustering, Massey and Denton (1988) suggest that Spatial Proximity (SP) is the best measure. The SP refers to the average of intra-group proximities weighted by the proportion of each group in the population. It equals 1 if there is no differential clustering between both groups (i.e. a certain minority group and white Britons); and is greater than one when members of both groups live nearer one another than each other. Indices were calculated with the Geo-Segregation Analyzer (Apparicio, Fournier \& Apparicio, 2012), an open-source software that works with geo-referenced data.

\section{Results}

\subsection{An overview of spatial segregation of (pooled) non-white ethnic minority groups (2001-2011)}

Figure 2 shows 2011 segregation indices (and their relationship and absolute difference with respect to 2001 indices) for (pooled) non-white ethnic minority groups, for each HMA. Bradford and Leicester show the highest levels of non-white ethnic minorities' segregation with respect to white British individuals, in all dimensions. Birmingham follows close, with relatively high segregation values in all dimensions. Reading, on the other hand, is in the opposite situation. In the middle, London and Luton \& Milton Keynes, show greater evenness, but also middle/high segregation in the other dimensions, implying that although in these HMA the non-white population is more evenly spread, they tend to live in small, clustered areas and with less interaction with white British individuals. Conversely, Manchester and Leeds show the opposite trend: non-white's spatial distribution is less even, but they are also less clustered, occupy larger spaces and have higher interaction with white British individuals.

10 (Pooled) non-whites and white British individuals sum up to more than $90 \%$ of the population of most HMAs, but never $100 \%$. For this reason IS is not symmetrical, and xPx and xPy do not add up to 1 (100\%). In London both groups sum up to around $85 \%$ (see Table A3). 
Figure 2. Relationship (first panel) and absolute difference (second panel) between 2011 and 2001 segregation indices of (pooled) non-white ethnic minorities in HMAs

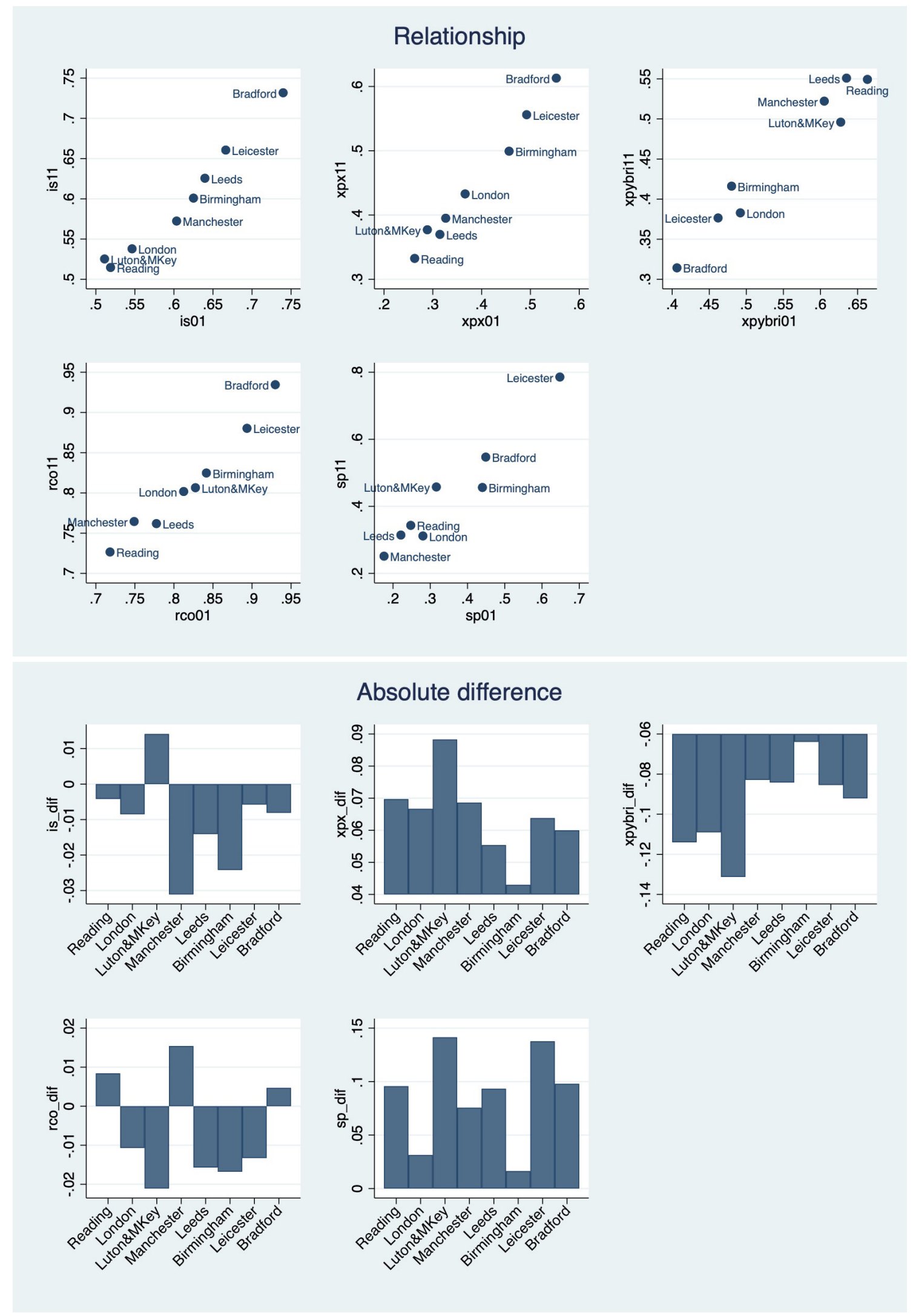

Source: 2001/2011 UK Census. Own elaboration 
Comparisons over time reveal some general tendencies. First, the relative position of HMAs in terms of segregation levels remains quite constant between both years (Figure 2, first panel). Second, non-white ethnic minorities were more evenly distributed in 2011 than in 2001 in all HMAs, except for Luton \& Milton Keynes. Third, due to the higher relative share of ethnic minorities in all HMAs (see Table A3), in 2011 non-white ethnic minorities were more exposed to each other and less exposed to white British individuals in the neighbourhood, compared to 2001. This is observed in the increases of $\mathrm{xPx}$ and decreases of xPy. Additional evidence (see Table A4) shows that areas (LSOAs) that had between 5 percent and 25 percent non-white ethnic minorities grew from 4651 to 5642 in the selected HMAs; at the same time, there is an increase in the number of areas with a high concentration (i.e. more than 70 percent) of non-white ethnic minorities (from 283 to 593). This hints to a parallel process by which, on the one hand, more ethnically mixed areas are created, and, on the other, areas that are predominantly non-white increase. Fourth, non-white ethnic minority groups are more clustered in 2011 than in 2001, which suggests that the observed dispersion (i.e. decrease in IS) occurs mostly to neighbouring areas, rather than to areas that are more distant. Finally, changes in levels of relative concentration vary across HMAs, with some areas experiencing an increase and others a decrease.

Some HMA-specific patterns also emerge. For example, Luton \& Milton Keynes is the only HMA where IS increased, and has also the highest increase in clustering of non-whites and the highest decrease in exposure to white British individuals. Birmingham is in the opposite situation, with the highest decreases in IS and one of the smallest increases in SP and $\mathrm{xPx}$. While part of the patterns observed might be related to the relative growth of non-whites (greater e.g. in Luton \& Milton Keynes, see Table A3), some HMAs might be more prone to segregation than others: e.g. the relative growth of non-whites in Bradford is comparable to that of Birmingham, but the former is worse positioned in terms of changes in segregation.

\subsection{Spatial segregation of ethnic minority groups (2011)}

Table A6 in the Annex shows segregation indices for 2011 and 2001 for each ethnic minority group in each HMA. I used cluster analysis (Ward connection method) to identify segregation patterns among the six groups located in the eight HMAs (48 cases in total). Through visual observation of the dendogram (see Figure Al in the Annex) I kept five clusters for 2001 and 2011 respectively (the comparison with 2001 is explored in section 3.3). Their key characteristics are shown in Figure 3, which shows the relationship between each group and segregation indices for both 2001 (hollow circles) and 2011 (black circles). The means of indices are also shown. There is a gradient in clusters going from the low, which shows the lowest segregation levels in all dimensions, to the high, showing the highest segregation levels in all dimensions. The midhigh cluster resembles the high cluster in the values of IS, but the other dimensions have lower segregation levels (yet higher compared to the other clusters). The main difference between the midlow and mid clusters is that the latter has on average higher IS and xPy. Overall, 2011 and 2001 clusterings are very similar.

Figure 4 shows the distribution of groups and HMAs in 2011 clusters. A first striking finding is that different groups tend to belong to the different cluster(s), independently of their HMA of residence. This means that segregation patterns are quite constant across groups, independently of the groups' location. Most Pakistanis and Bangladeshis belong to the midhigh and high segregation clusters. Note that though Bangladeshis tend to be more unevenly distributed than Pakistanis (see Table A6), they often have lower levels of segregation in other dimensions, hence predominating in the midhigh cluster (except for London). Africans and Caribbeans, and most Indians, belong to the mid and midlow clusters. Finally, all Chinese belong to the midlow and low clusters. Inspection of Table A6 also points to two cases of very high segregation, which approach or surpass the thresholds established by Massey and Denton (1988) to identify "highly segregated" groups (see also Massey \& Tannen, 2018). Those are Pakistanis in Bradford and Indians in Leicester. Not only do their IS go beyond the threshold value of 0.6 , but also these groups have very high exposure to co-ethnics ( 0.49 and 0.44 respectively, the closest to the threshold established by Massey and Denton for this index: $\mathrm{xPx}=0.7)$ and high levels of clustering, reaching or surpassing the 0.6 threshold. 
Figure 3. Relationship between clusters and segregation indices of ethnic minority groups in HMAs (upper figure); detail of clusters (bottom table). 2001/2011

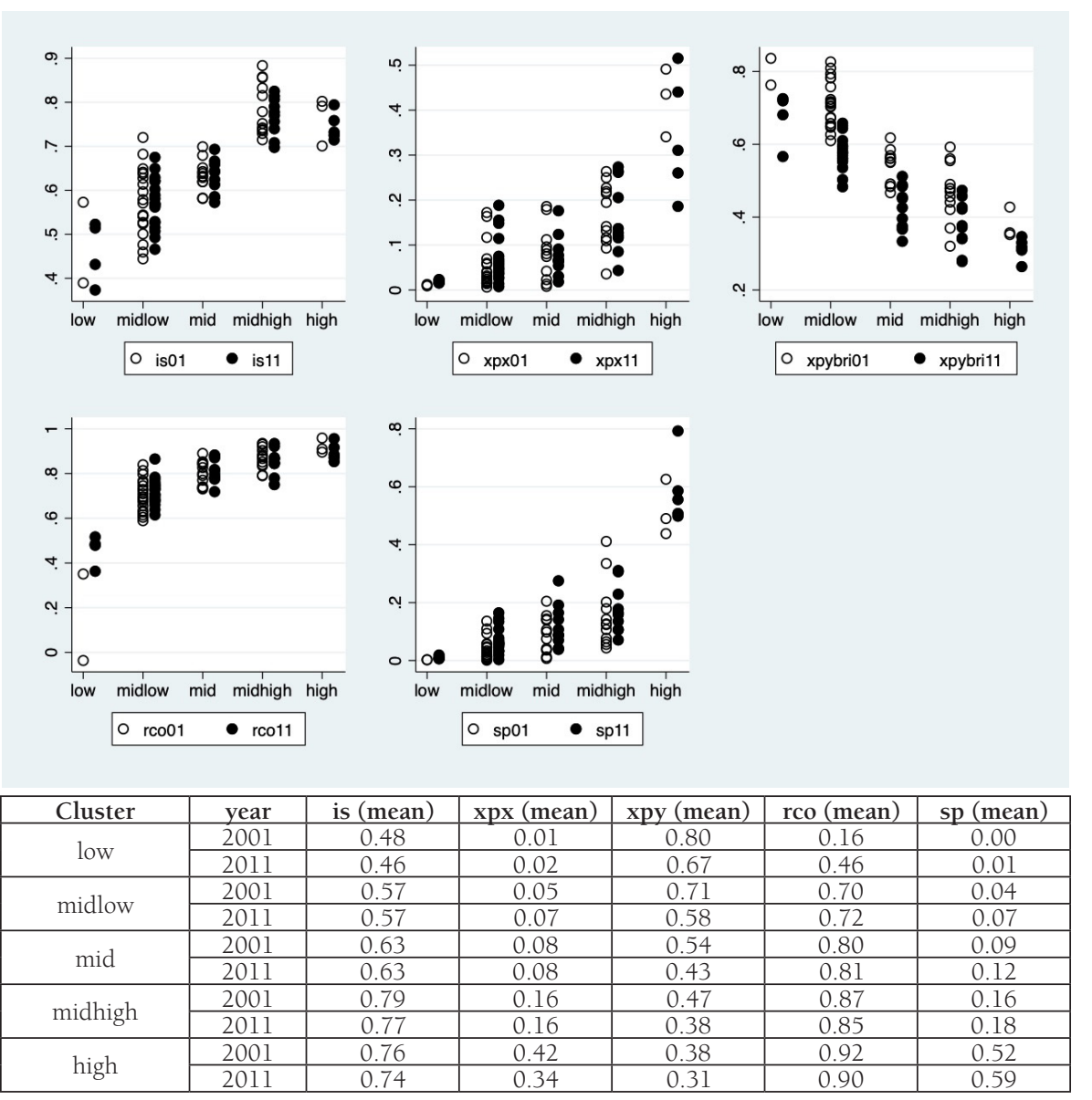

$\mathrm{N}=48$. Source: $2001 / 2011$ UK Census. Own Elaboration

Figure 4. Distribution of ethnic minority groups and HMAs in clusters, 2011

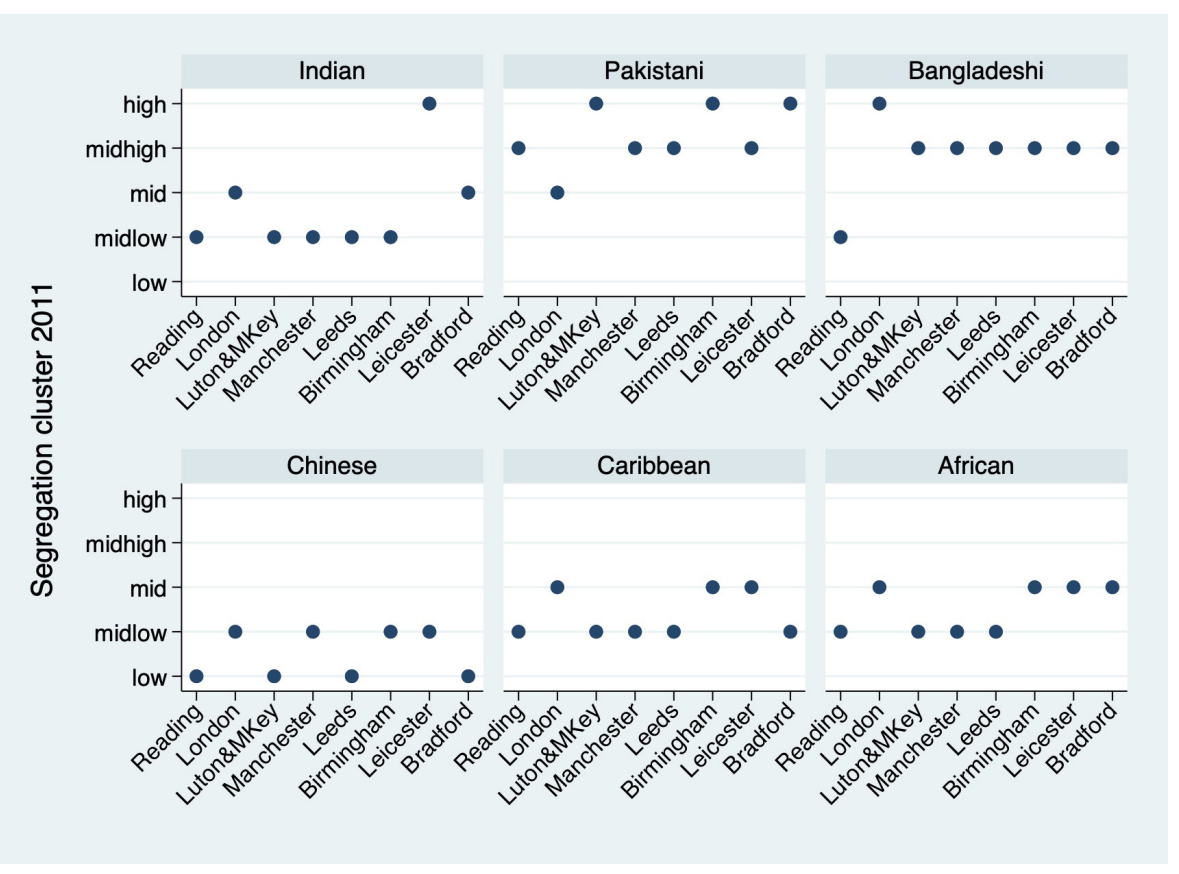

Source: 2011 UK Census. Own elaboration 


\subsection{Changes in spatial segregation of ethnic minority groups (2001-2011)}

Figure 5 compares how groups and HMAs distribute in 2001 and 2011 clusters, while Figure 6 shows the absolute differences in indices between both years. The relative position of groups/HMAs did not vary much between both years, with Pakistanis and Bangladeshis often being the most segregated, Indian, Caribbean and African occupying intermediate positions, and the Chinese having the lowest segregation levels (see Figure 5). Some findings deserve, nevertheless, some attention (see Figure 6).

First, Caribbeans present greater number of improvements or limited changes in segregation between 2001 and 2011: a key characteristic is their decrease in within-group interaction (xPx) in almost all HMAs. Second, Bangladeshis also present several improvements, and they clearly differentiate from the other mostly segregated group, Pakistanis. Compared to Pakistanis, Bangladeshis are much less likely to have increased their within-group interaction in most HMAs; the increase of clustering, although positive for all groups, is less prominent for Bangladeshis too; in addition, Bangladeshis have reduced their uneven distribution in all HMAs. These patterns also hold if one compares Pakistanis in Bradford and Bangladeshis in London, the two HMAs where the groups present the highest segregation levels in 2011. Supporting this finding, additional information (see Table A5) shows that while the number of areas (LSOAs) with more than 50 percent of Bangladeshis in the selected HMAs decreased from 28 to 25 (in London from 24 to 20, with no LSOAs above 70\%), for Pakistanis it increased from 88 to 128 (in Bradford from 40 to 58). A visual representation of those changes is shown in Figures A2 and A3 in the Annex. Third, Indians in Leicester, another highly segregated case, have one of the highest increases in the SP index, as well as an increase in their uneven distribution and exposure to co-ethnics, which appears as a worrisome trend. Table A5 also shows that neighbourhoods with 70 percent or more of Indian population (which are all located in Leicester, except for one) grew from 17 to 22. A last interesting finding regards the more favourable segregation patterns observed in Birmingham, already highlighted in the previous section. These improvements apply mainly to the two majoritarian ethnic minority populations: Indians and Pakistanis. In this HMA, both groups show reductions in IS, xPx (this is the only area where a reduction in $\mathrm{xPx}$ is observed for Pakistanis) and SP (Indian only).

Figure 5. Relationship between 2001 and 2011 clusters; ethnic minority groups in HMAs

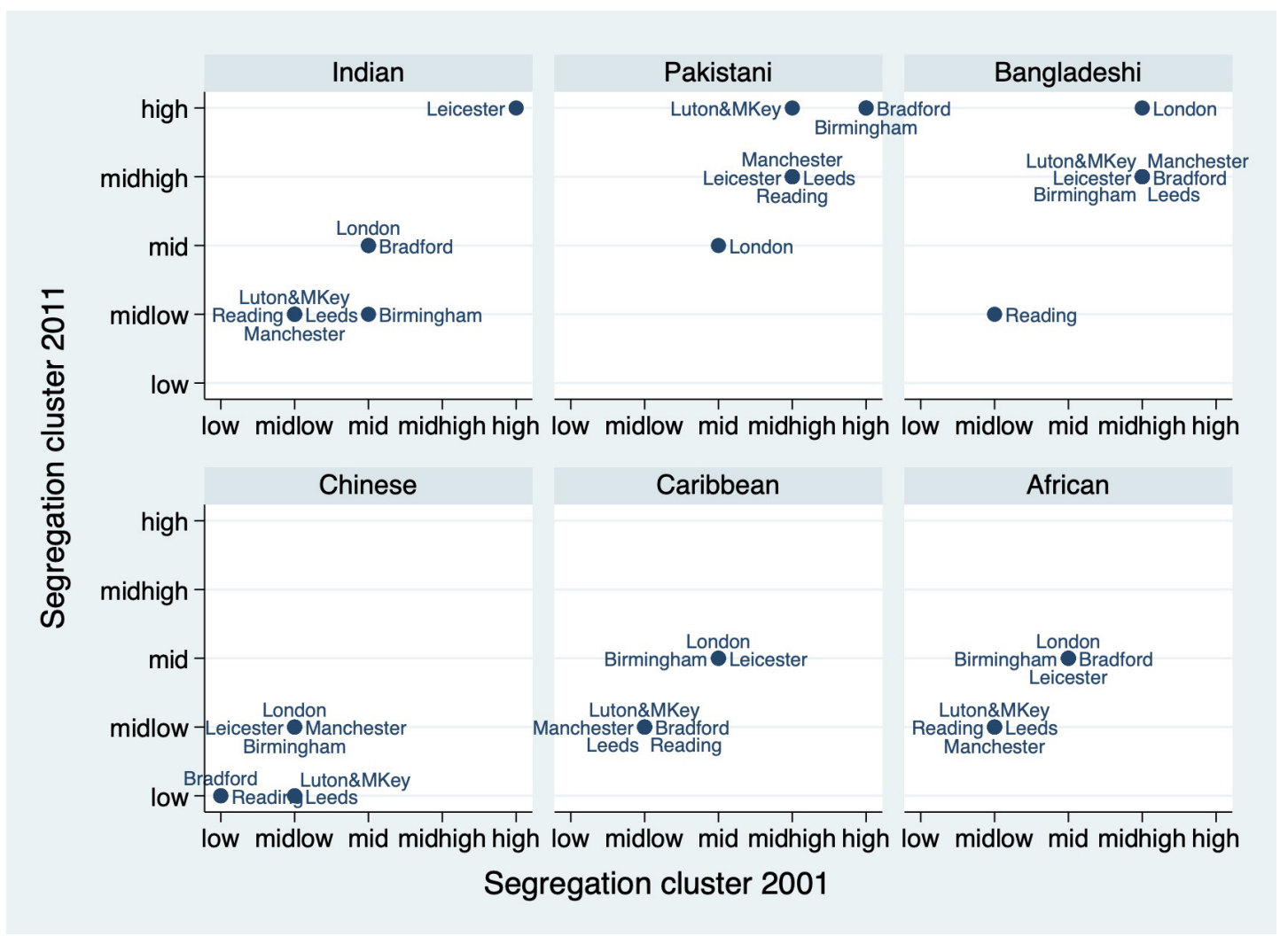

Source: 2001/2011 UK Census. Own elaboration 
Figure 6. Absolute difference between 2011 and 2001 segregation indices of ethnic minority groups in HMAs
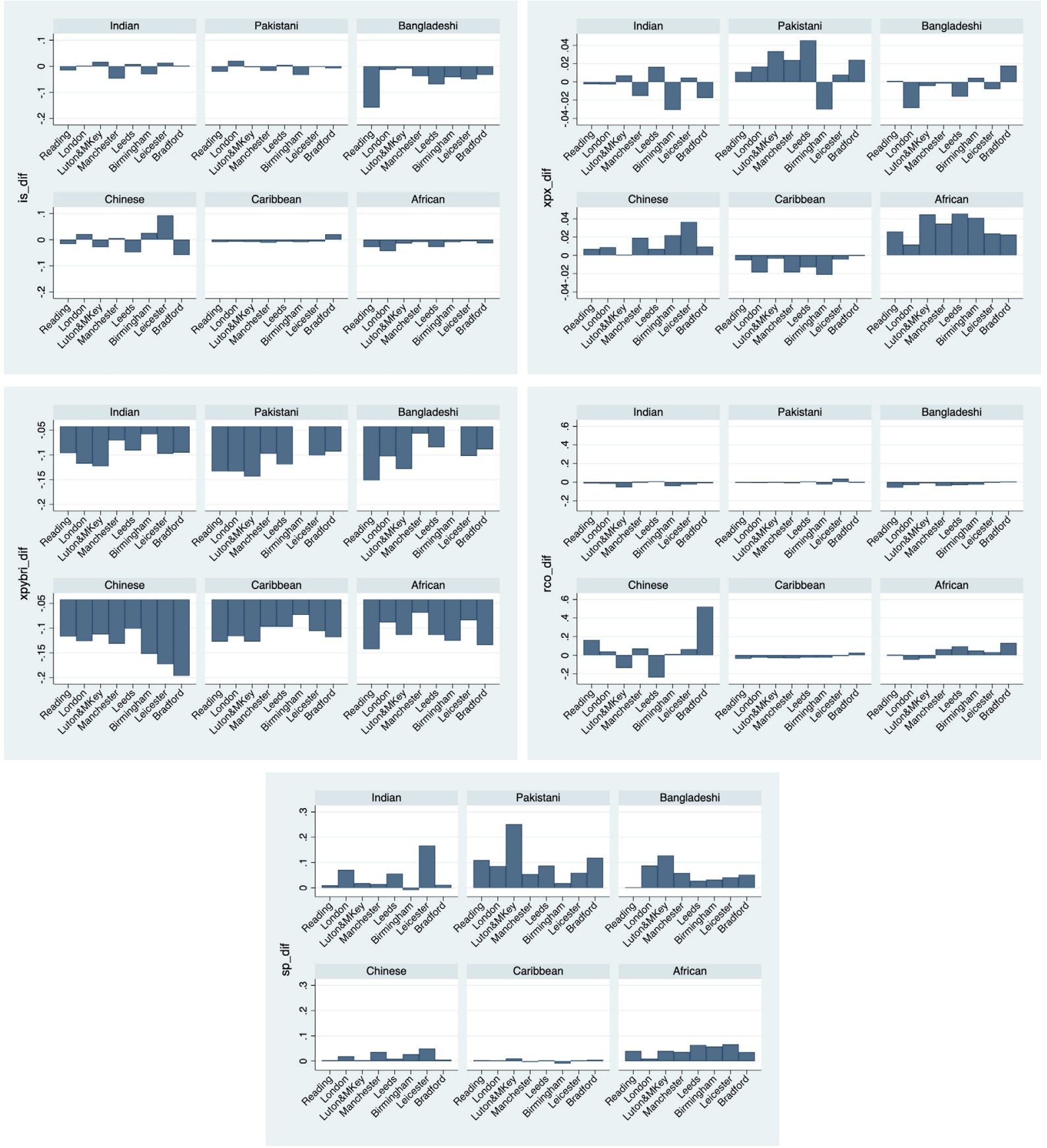

Source: 2001/2011 UK Census. Own elaboration

\section{Discussion}

Using empirically defined housing markets, the paper has explored levels and patterns of change in spatial segregation for the most numerous non-white ethnic groups in eight housing market areas in England, between 2001 and 2011. The study identifies both ethnic and context configurations associated to levels of and changes in spatial segregation. In other words, while some segregation patterns seem to be specific to the ethnic groups studied, others seem to be more associated to certain locations or to certain groups residing in certain locations.

As regards ethnic configurations, the study has identified well-known segregation patterns already highlighted by previous studies. The high levels of spatial segregation of Pakistanis and Bangladeshis 
(e.g. Simpson (2012)) were, for example, observed in most locations studied, while the low segregation of Chinese was also found in most locations. Most importantly, the study showed that different groups tended to belong to different identified segregation clusters, independently of their HMA of residence. In other words, ethnic minority groups' segregation patterns were, in general, maintained across locations. Some changes in segregation levels also seemed to be associated to ethnic configurations. In this respect, one of the most interesting findings of this study pertains the ethnic-specific and, at the same time, divergent patterns of change experienced by the Pakistani and Bangladeshi populations: the latter were, in general, much better positioned in terms of changes in levels of segregation, with higher decreases (or less pronounced increases) in the various indices studied. The fact that the observed differences between Pakistanis and Bangladeshis occurred systematically in most HMAs (with the exception of Birmingham) suggests that, rather to a specific urban context, the varied patterns of change in segregation levels are likely to be associated to characteristics of the groups. It is, nevertheless, a surprising finding that deserves some reflection. Both groups are actually very similar in terms of segregation levels, components of population growth (equally divided between natural change and net migration Simpson (2013)), and cultural and religious characteristics (Dale, Fieldhouse, Shaheen, \& Kalra, 2002; Heath \& Martin, 2013; Peach, 2005). In addition, Bangladeshis have a higher proportion of foreign-born population and have spent less time in the country, on average. ${ }^{11}$ With this evidence we could have expected more similar (or perhaps inverted) patterns of change. While more research is needed to disentangle these contrasting ethnic configurations associated to segregation patterns, there are some factors - connected to minorities' socioeconomic resources and how they use them - that may help shed light on this. Recent studies show that Pakistanis' and Bangladeshis' spatial opportunities are highly dependent on their socioeconomic characteristics (Coulter \& Clark, 2018; Zuccotti, 2019). At the same time, there is also evidence that second generation Bangladeshis are doing better than Pakistanis on a series of educational and labour market outcomes (Zuccotti \& Platt, 2019). This evidence suggests that, over time, Bangladeshis might have more opportunities for spatial integration. Other explanations might be associated to differentiated preferences and constraints, mechanisms that have largely been debated by the literature on spatial integration (Krysan \& Crowder, 2017): both mechanisms should be the object of future empirical research.

Conversely, some segregation patterns seem to be more associated to certain locations, i.e. with context configurations. Indians have particularly high segregation levels in Leicester, but not in other areas. Bradford also appears as an unfavourable context for segregation, especially for the Pakistani population. These patterns might speak of context configurations, associated not only to the characteristics of Leicester's and Bradford's housing markets but also with historical ethnic relations in these locations or with specific characteristics of Indians and Pakistanis who reside there. In particular, Bradford was the centre of riots involving young white Britons and Pakistanis in the early 2000s, which were connected to factors such as economic deprivation, housing discrimination and increasing separation and antagonism between ethnic minorities and whites. Although the idea that Asians and whites in this location live 'parallel lives' (Rattansi, 2011; Uslaner, 2012) has been challenged (Finney \& Simpson, 2009b; Heath $\&$ Demireva, 2013), and migration and natural growth play an important role in segregation (Finney \& Simpson, 2009a), there is still evidence of strong bonding ties among the Asian population as well as evidence of discrimination and harassment in this location (Carling, 2008). This might be pushing processes of self-segregation of both whites and non-whites. To reinforce this argument, it is interesting to observe that the situation in Birmingham is quite different. In this location, change in levels of segregation are much more favourable for most groups, including Indians and Pakistanis, who constitute the majority of non-white population who resides there. This is something that would deserve further research, and which indeed reveals that a highly segregated population such as Pakistanis do not necessarily follow the same patterns of change across different locations.

\section{Conclusions}

Neighbourhood ethnic segregation, both in the UK and elsewhere, has been a matter of interest to both researchers and policy makers. The multiple comparisons presented in this study have allowed identifying configurations that are specific to certain ethnic groups and configurations that are specific to certain contexts (or to certain groups in certain contexts). In so doing, the study highlights that both

11 https://www.ons.gov.uk/aboutus/transparencyandgovernance/freedomofinformationfoi/populationandrace 
the characteristics of ethnic groups and that of residential contexts can be equally relevant when trying to understand the reasons behind certain segregation patterns. This, I believe, is an important lesson for future segregation research, both in the UK and elsewhere, especially in light of the forthcoming censuses in several European countries.

Another added value of this study, and something that should be considered by researchers and policy makers, is the use of HMAs to study segregation, rather than other geographical areas such as cities or local authorities. HMAs are proxies of the maximum distance that an individual might be willing to move to change residence. As such, they acknowledge that residential moves are not random, but often happen within certain geographical limits. To the extent that segregation is at least partly associated with residential moves, it is important to acknowledge this phenomenon. The study of segregation with such meaningful spatial frameworks that this paper proposes is, therefore, a first step in this agenda. HMAs can hence become key areas not only for urban planning (Jones, Coombes \& Wong, 2010), but also for developing policies that counteract segregation. While the HMAs that I used are specific to the UK, the same methodology and rationale could be applied in other countries.

\section{Annex}

Table A1. Descriptive statistics for housing market areas: population and land area (2011)

\begin{tabular}{lcccccc}
\hline & \multicolumn{3}{c}{ General characteristics of HMAs } & \multicolumn{2}{c}{ Characteristics of LSOAs within HMAs } \\
\cline { 2 - 6 } Housing market area & & Pumber of & $\begin{array}{c}\text { Land area } \\
\text { (km2) }\end{array}$ & $\begin{array}{c}\text { \% LOAs } \\
\text { with land area } \\
\text { (km2) below } \\
\text { the median }\end{array}$ & $\begin{array}{c}\text { \% LSOAs with } \\
\text { population } \\
\text { density above } \\
\text { the median }\end{array}$ & $\begin{array}{c}\text { Average } \\
\text { population of } \\
\text { LSOAs }\end{array}$ \\
\hline London & 12207124 & 7334 & 7974.84 & 70.6 & 71.5 & 1664 \\
Reading & 1380252 & 864 & 2611.72 & 42.1 & 43.4 & 1598 \\
Luton \& Milton Keynes & 977128 & 611 & 2285.81 & 48.1 & 48.1 & 1599 \\
Birmingham & 3032813 & 1881 & 3102.32 & 59.6 & 60.1 & 1612 \\
Leicester & 949342 & 570 & 2140.17 & 40.9 & 41.8 & 1666 \\
Manchester & 2576017 & 1609 & 2259.12 & 57.2 & 56.4 & 1601 \\
Leeds & 1806686 & 1154 & 2893.01 & 40.8 & 39.1 & 1566 \\
Bradford & 764664 & 460 & 1903.28 & 46.1 & 46.3 & 1662 \\
\hline
\end{tabular}

Source: 2011 UK Census. Own Elaboration

Table A2. Distribution of British and ethnic minorities in England in 2001-2011 (row \%) and across housing market areas in 2011 (column \%)

\begin{tabular}{|c|c|c|c|c|c|c|c|c|}
\hline & White British & All non-white & Indian & Pakistani & Bangladeshi & Chinese & Caribbean & African \\
\hline \multicolumn{9}{|l|}{ England } \\
\hline 2001 & 87.17 & 7.63 & 2.09 & 1.40 & 0.54 & 0.44 & 1.12 & 0.94 \\
\hline 2011 & 80.09 & 12.08 & 2.60 & 2.08 & 0.81 & 0.66 & 1.10 & 1.79 \\
\hline \multicolumn{9}{|l|}{ HMAs (2011) } \\
\hline London & 17.7 & 50.0 & 45.6 & 23.4 & 54.8 & 41.7 & 62.5 & 66.1 \\
\hline Reading & 2.6 & 3.1 & 3.9 & 5.0 & 0.9 & 2.5 & 2.2 & 2.3 \\
\hline Luton \& Milton Keynes & 1.8 & 2.7 & 2.2 & 3.9 & 4.6 & 1.9 & 2.7 & 2.8 \\
\hline Birmingham & 5.5 & 9.8 & 11.5 & 16.5 & 9.9 & 4.5 & 13.0 & 4.3 \\
\hline Leicester & 1.7 & 3.1 & 8.8 & 0.9 & 1.4 & 2.0 & 1.0 & 1.5 \\
\hline Manchester & 5.0 & 5.7 & 3.9 & 11.9 & 8.2 & 6.4 & 3.0 & 4.3 \\
\hline Leeds & 3.8 & 2.9 & 2.8 & 6.3 & 1.3 & 2.3 & 2.0 & 2.0 \\
\hline Bradford & 1.4 & 2.7 & 1.1 & 11.0 & 2.2 & 0.7 & 0.7 & 0.6 \\
\hline Rest of England & 60.6 & 19.9 & 20.3 & 20.9 & 16.7 & 37.9 & 12.8 & 16.1 \\
\hline Total & 40925897 & 6172142 & 1327640 & 1063792 & 412420 & 338522 & 564593 & 914097 \\
\hline
\end{tabular}


Table A3. Distribution of white British and ethnic minorities within HMAs (row \%); 2001 and 2011

\begin{tabular}{|c|c|c|c|c|c|c|c|c|c|}
\hline & White British & All non-white & Indian & Pakistani & Bangladeshi & Chinese & Caribbean & African & Total \\
\hline \multicolumn{10}{|l|}{2001} \\
\hline London & 71.5 & 17.5 & 4.3 & 1.4 & 1.4 & 0.9 & 3.1 & 3.4 & 11048707 \\
\hline Reading & 85.9 & 7.9 & 2.5 & 2.5 & 0.1 & 0.4 & 0.9 & 0.5 & 1301306 \\
\hline Luton \& Milton Keynes & 83.9 & 9.8 & 2.2 & 2.7 & 1.2 & 0.5 & 1.5 & 0.8 & 913868 \\
\hline Birmingham & 82.0 & 13.4 & 4.5 & 4.1 & 0.8 & 0.3 & 2.4 & 0.3 & 2857091 \\
\hline Leicester & 82.7 & 13.7 & 10.2 & 0.6 & 0.4 & 0.4 & 0.6 & 0.4 & 868892 \\
\hline Manchester & 88.0 & 7.5 & 1.5 & 3.0 & 0.8 & 0.5 & 0.6 & 0.4 & 2426500 \\
\hline Leeds & 91.0 & 5.9 & 1.7 & 2.5 & 0.2 & 0.3 & 0.6 & 0.2 & 1725523 \\
\hline Bradford & 82.0 & 14.7 & 1.8 & 10.7 & 0.6 & 0.2 & 0.5 & 0.2 & 702005 \\
\hline \multicolumn{10}{|l|}{2011} \\
\hline London & 59.3 & 25.3 & 5.0 & 2.0 & 1.9 & 1.2 & 2.9 & 4.9 & 12207124 \\
\hline Reading & 77.2 & 14.0 & 3.8 & 3.9 & 0.3 & 0.6 & 0.9 & 1.5 & 1380252 \\
\hline Luton \& Milton Keynes & 73.5 & 17.0 & 2.9 & 4.3 & 2.0 & 0.6 & 1.6 & 2.6 & 977128 \\
\hline Birmingham & 73.7 & 20.0 & 5.0 & 5.8 & 1.3 & 0.5 & 2.4 & 1.3 & 3032813 \\
\hline Leicester & 74.6 & 19.9 & 12.3 & 1.0 & 0.6 & 0.7 & 0.6 & 1.4 & 949342 \\
\hline Manchester & 80.2 & 13.7 & 2.0 & 4.9 & 1.3 & 0.8 & 0.7 & 1.5 & 2576017 \\
\hline Leeds & 85.3 & 9.8 & 2.0 & 3.7 & 0.3 & 0.4 & 0.6 & 1.0 & 1806686 \\
\hline Bradford & 72.6 & 22.1 & 1.8 & 15.4 & 1.2 & 0.3 & 0.5 & 0.7 & 764664 \\
\hline
\end{tabular}

Source: 2001/2011 UK Census. Own Elaboration

Table A4. Number of LSOAs with different shares of non-white ethnic minorities (2001 and 2011); selected HMAs

\begin{tabular}{|c|c|c|c|c|c|c|c|}
\hline & 2001 & & & & & & \\
\hline 2011 & $70 \%$ and more & $50.01 \%-70 \%$ & $25.01 \%-50 \%$ & $10.01 \%-25 \%$ & $5.01 \%-10 \%$ & Up to $5 \%$ & Total \\
\hline $70 \%+$ & 277 & 280 & 35 & 1 & 0 & 0 & 593 \\
\hline $50.01 \%-70 \%$ & 5 & 326 & 698 & 27 & 3 & 0 & 1059 \\
\hline $25.01 \%-50 \%$ & 1 & 9 & 1165 & 1,278 & 126 & 19 & 2598 \\
\hline $10.01 \%-25 \%$ & 0 & 0 & 23 & 1,281 & 1,445 & 584 & 3333 \\
\hline $5.01 \%-10 \%$ & 0 & 0 & 0 & 11 & 458 & 1840 & 2309 \\
\hline Up to $5 \%$ & 0 & 0 & 0 & 0 & 21 & 4570 & 4591 \\
\hline Total & 283 & 615 & 1921 & 2598 & 2053 & 7013 & 14,483 \\
\hline
\end{tabular}

Source: 2001/2011 UK Census. Own Elaboration

Table A5. Number of LSOAs with different shares of ethnic minorities, by ethnic group (2001 and 2011); selected HMAs

\begin{tabular}{|c|c|c|c|c|c|c|c|}
\hline & 2001 & & & & & & \\
\hline 2011 & $70 \%$ and more & $50.01 \%-70 \%$ & $25.01 \%-50 \%$ & $10.01 \%-25 \%$ & $5.01 \%-10 \%$ & Up to $5 \%$ & Total \\
\hline \multicolumn{8}{|l|}{ Indian } \\
\hline $70 \%+$ & 17 & 5 & 0 & 0 & 0 & 0 & 22 \\
\hline $50.01 \%-70 \%$ & 0 & 34 & 18 & 0 & 0 & 0 & 52 \\
\hline $25.01 \%-50 \%$ & 0 & 24 & 274 & 104 & 2 & 0 & 404 \\
\hline $10.01 \%-25 \%$ & 0 & 0 & 60 & 601 & 254 & 49 & 964 \\
\hline $5.01 \%-10 \%$ & 0 & 0 & 0 & 131 & 672 & 712 & 1,515 \\
\hline Up to $5 \%$ & 0 & 0 & 0 & 2 & 272 & 11,252 & 11,526 \\
\hline Total & 17 & 63 & 352 & 838 & 1,200 & 12,013 & 14,483 \\
\hline \multicolumn{8}{|l|}{ Pakistani } \\
\hline $70 \%+$ & 10 & 11 & 0 & 0 & 0 & 0 & 21 \\
\hline $50.01 \%-70 \%$ & 3 & 58 & 43 & 3 & 0 & 0 & 107 \\
\hline $25.01 \%-50 \%$ & 0 & 6 & 148 & 126 & 9 & 5 & 294 \\
\hline $10.01 \%-25 \%$ & 0 & 0 & 3 & 346 & 277 & 123 & 749 \\
\hline $5.01 \%-10 \%$ & 0 & 0 & 0 & 20 & 295 & 606 & 921 \\
\hline Up to $5 \%$ & 0 & 0 & 0 & 0 & 52 & 12,339 & 12,391 \\
\hline Total & 13 & 75 & 194 & 495 & 633 & 13,073 & 14,483 \\
\hline
\end{tabular}




\begin{tabular}{|c|c|c|c|c|c|c|c|}
\hline & 2001 & & & & & & \\
\hline 2011 & $70 \%$ and more & $50.01 \%-70 \%$ & $25.01 \%-50 \%$ & $10.01 \%-25 \%$ & $5.01 \%-10 \%$ & Up to $5 \%$ & Total \\
\hline \multicolumn{8}{|l|}{ Bangladeshi } \\
\hline $70 \%+$ & 1 & 1 & 0 & 0 & 0 & 0 & 2 \\
\hline $50.01 \%-70 \%$ & 2 & 16 & 5 & 0 & 0 & 0 & 23 \\
\hline $25.01 \%-50 \%$ & 0 & 8 & 60 & 26 & 1 & 1 & 96 \\
\hline $10.01 \%-25 \%$ & 0 & 0 & 8 & 154 & 80 & 56 & 298 \\
\hline $5.01 \%-10 \%$ & 0 & 0 & 0 & 10 & 139 & 240 & 389 \\
\hline Up to $5 \%$ & 0 & 0 & 0 & 0 & 42 & 13,633 & 13,675 \\
\hline Total & 3 & 25 & 73 & 190 & 262 & 13,930 & 14,483 \\
\hline \multicolumn{8}{|l|}{ Chinese } \\
\hline $10.01 \%-25 \%$ & & & & 1 & 14 & 13 & 28 \\
\hline $5.01 \%-10 \%$ & & & & 1 & 30 & 105 & 136 \\
\hline Up to $5 \%$ & & & & 1 & 22 & 14,296 & 14,319 \\
\hline Total & & & & 3 & 66 & 14,414 & 14,483 \\
\hline \multicolumn{8}{|l|}{ Caribbean } \\
\hline $25.01 \%-50 \%$ & & & 2 & 2 & 0 & 0 & 4 \\
\hline $10.01 \%-25 \%$ & & & 17 & 502 & 49 & 3 & 571 \\
\hline $5.01 \%-10 \%$ & & & 0 & 295 & 712 & 164 & 1,171 \\
\hline Up to $5 \%$ & & & 0 & 3 & 427 & 12,307 & 12,737 \\
\hline Total & & & 19 & 802 & 1,188 & 12,474 & 14,483 \\
\hline \multicolumn{8}{|l|}{ African } \\
\hline $25.01 \%-50 \%$ & & & 45 & 53 & 12 & 1 & 111 \\
\hline $10.01 \%-25 \%$ & & & 14 & 488 & 331 & 237 & 1,070 \\
\hline $5.01 \%-10 \%$ & & & 0 & 80 & 524 & 980 & 1,584 \\
\hline Up to $5 \%$ & & & 0 & 2 & 145 & 11,571 & 11,718 \\
\hline Total & & & 59 & 623 & 1,012 & 12,789 & 14,483 \\
\hline
\end{tabular}

Source: 2001/2011 UK Census. Own Elaboration

Table A6. Segregation indices for ethnic minority groups in 2001 and 2011; HMAs

\begin{tabular}{|c|c|c|c|c|c|c|c|c|c|c|c|}
\hline & & 2001 & & & & & 2011 & & & & \\
\hline HMA & group & is & $\mathrm{xpx}$ & xpybri & rco & sp & is & $\mathrm{xpx}$ & xpybri & rco & $\mathrm{sp}$ \\
\hline Birmingham & Indian & 0.62 & 0.19 & 0.56 & 0.77 & 1.14 & 0.59 & 0.16 & 0.50 & 0.73 & 1.13 \\
\hline Birmingham & Pakistani & 0.79 & 0.34 & 0.35 & 0.90 & 1.49 & 0.76 & 0.31 & 0.31 & 0.87 & 1.51 \\
\hline Birmingham & Bangladeshi & 0.83 & 0.12 & 0.32 & 0.88 & 1.13 & 0.79 & 0.12 & 0.28 & 0.85 & 1.16 \\
\hline Birmingham & Chinese & 0.54 & 0.02 & 0.71 & 0.63 & 1.01 & 0.57 & 0.04 & 0.56 & 0.64 & 1.03 \\
\hline Birmingham & Caribbean & 0.58 & 0.09 & 0.56 & 0.80 & 1.10 & 0.57 & 0.07 & 0.49 & 0.78 & 1.09 \\
\hline Birmingham & African & 0.65 & 0.01 & 0.55 & 0.73 & 1.01 & 0.64 & 0.05 & 0.43 & 0.78 & 1.07 \\
\hline Bradford & Indian & 0.64 & 0.08 & 0.55 & 0.89 & 1.08 & 0.64 & 0.06 & 0.45 & 0.88 & 1.09 \\
\hline Bradford & Pakistani & 0.80 & 0.49 & 0.36 & 0.96 & 1.44 & 0.79 & 0.52 & 0.26 & 0.96 & 1.56 \\
\hline Bradford & Bangladeshi & 0.86 & 0.11 & 0.37 & 0.93 & 1.06 & 0.83 & 0.13 & 0.28 & 0.93 & 1.11 \\
\hline Bradford & Chinese & 0.57 & 0.01 & 0.76 & -0.04 & 1.00 & 0.51 & 0.02 & 0.57 & 0.48 & 1.01 \\
\hline Bradford & Caribbean & 0.54 & 0.01 & 0.67 & 0.84 & 1.01 & 0.57 & 0.01 & 0.56 & 0.87 & 1.02 \\
\hline Bradford & African & 0.68 & 0.01 & 0.59 & 0.74 & 1.01 & 0.67 & 0.03 & 0.45 & 0.87 & 1.04 \\
\hline Leeds & Indian & 0.64 & 0.17 & 0.63 & 0.73 & 1.11 & 0.65 & 0.19 & 0.54 & 0.74 & 1.16 \\
\hline Leeds & Pakistani & 0.75 & 0.22 & 0.59 & 0.84 & 1.14 & 0.76 & 0.26 & 0.47 & 0.84 & 1.23 \\
\hline Leeds & Bangladeshi & 0.88 & 0.13 & 0.46 & 0.90 & 1.04 & 0.81 & 0.12 & 0.37 & 0.87 & 1.07 \\
\hline Leeds & Chinese & 0.57 & 0.02 & 0.83 & 0.60 & 1.01 & 0.52 & 0.02 & 0.73 & 0.36 & 1.02 \\
\hline Leeds & Caribbean & 0.68 & 0.07 & 0.67 & 0.77 & 1.06 & 0.68 & 0.06 & 0.57 & 0.74 & 1.06 \\
\hline Leeds & African & 0.65 & 0.01 & 0.76 & 0.66 & 1.01 & 0.62 & 0.06 & 0.64 & 0.75 & 1.08 \\
\hline Leicester & Indian & 0.70 & 0.44 & 0.43 & 0.91 & 1.63 & 0.71 & 0.44 & 0.33 & 0.88 & 1.79 \\
\hline
\end{tabular}




\begin{tabular}{|c|c|c|c|c|c|c|c|c|c|c|c|}
\hline & & 2001 & & & & & 2011 & & & & \\
\hline HMA & group & is & $\mathrm{xpx}$ & xpybri & rco & $\mathrm{sp}$ & is & $\mathrm{xpx}$ & xpybri & rco & $\mathrm{sp}$ \\
\hline Leicester & Pakistani & 0.74 & 0.04 & 0.44 & 0.83 & 1.08 & 0.74 & 0.04 & 0.34 & 0.87 & 1.14 \\
\hline Leicester & Bangladeshi & 0.86 & 0.09 & 0.48 & 0.87 & 1.06 & 0.81 & 0.09 & 0.38 & 0.87 & 1.11 \\
\hline Leicester & Chinese & 0.53 & 0.02 & 0.78 & 0.71 & 1.01 & 0.62 & 0.05 & 0.61 & 0.77 & 1.06 \\
\hline Leicester & Caribbean & 0.62 & 0.02 & 0.62 & 0.83 & 1.04 & 0.61 & 0.02 & 0.51 & 0.82 & 1.04 \\
\hline Leicester & African & 0.70 & 0.04 & 0.57 & 0.85 & 1.04 & 0.69 & 0.07 & 0.48 & 0.88 & 1.11 \\
\hline London & Indian & 0.58 & 0.18 & 0.48 & 0.74 & 1.20 & 0.58 & 0.18 & 0.37 & 0.72 & 1.28 \\
\hline London & Pakistani & 0.64 & 0.07 & 0.47 & 0.79 & 1.11 & 0.66 & 0.09 & 0.33 & 0.78 & 1.19 \\
\hline London & Bangladeshi & 0.74 & 0.21 & 0.42 & 0.88 & 1.41 & 0.73 & 0.19 & 0.32 & 0.85 & 1.50 \\
\hline London & Chinese & 0.44 & 0.02 & 0.61 & 0.63 & 1.01 & 0.47 & 0.03 & 0.48 & 0.67 & 1.03 \\
\hline London & Caribbean & 0.63 & 0.10 & 0.49 & 0.84 & 1.14 & 0.62 & 0.08 & 0.38 & 0.82 & 1.14 \\
\hline London & African & 0.63 & 0.11 & 0.48 & 0.85 & 1.16 & 0.59 & 0.12 & 0.40 & 0.80 & 1.16 \\
\hline Luton\&Mkeynes & Indian & 0.48 & 0.06 & 0.72 & 0.76 & 1.05 & 0.49 & 0.06 & 0.59 & 0.70 & 1.07 \\
\hline Luton\&Mkeynes & Pakistani & 0.74 & 0.23 & 0.49 & 0.92 & 1.34 & 0.73 & 0.26 & 0.35 & 0.92 & 1.59 \\
\hline Luton\&Mkeynes & Bangladeshi & 0.78 & 0.14 & 0.47 & 0.94 & 1.18 & 0.77 & 0.14 & 0.34 & 0.92 & 1.31 \\
\hline Luton\&Mkeynes & Chinese & 0.46 & 0.02 & 0.79 & 0.62 & 1.00 & 0.43 & 0.02 & 0.68 & 0.48 & 1.01 \\
\hline Luton\&Mkeynes & Caribbean & 0.52 & 0.04 & 0.71 & 0.81 & 1.04 & 0.52 & 0.04 & 0.58 & 0.78 & 1.06 \\
\hline Luton\&Mkeynes & African & 0.54 & 0.02 & 0.70 & 0.80 & 1.02 & 0.53 & 0.07 & 0.59 & 0.76 & 1.06 \\
\hline Manchester & Indian & 0.63 & 0.16 & 0.65 & 0.68 & 1.09 & 0.58 & 0.15 & 0.58 & 0.68 & 1.11 \\
\hline Manchester & Pakistani & 0.71 & 0.25 & 0.55 & 0.79 & 1.12 & 0.70 & 0.27 & 0.46 & 0.78 & 1.18 \\
\hline Manchester & Bangladeshi & 0.82 & 0.26 & 0.48 & 0.79 & 1.11 & 0.78 & 0.26 & 0.42 & 0.75 & 1.17 \\
\hline Manchester & Chinese & 0.50 & 0.03 & 0.78 & 0.59 & 1.01 & 0.51 & 0.05 & 0.65 & 0.66 & 1.05 \\
\hline Manchester & Caribbean & 0.61 & 0.06 & 0.65 & 0.73 & 1.06 & 0.60 & 0.04 & 0.55 & 0.69 & 1.05 \\
\hline Manchester & African & 0.64 & 0.04 & 0.65 & 0.69 & 1.03 & 0.63 & 0.08 & 0.58 & 0.75 & 1.07 \\
\hline Reading & Indian & 0.54 & 0.12 & 0.66 & 0.70 & 1.14 & 0.53 & 0.11 & 0.56 & 0.68 & 1.15 \\
\hline Reading & Pakistani & 0.73 & 0.19 & 0.56 & 0.85 & 1.20 & 0.71 & 0.21 & 0.43 & 0.84 & 1.31 \\
\hline Reading & Bangladeshi & 0.72 & 0.01 & 0.81 & 0.68 & 1.00 & 0.56 & 0.01 & 0.66 & 0.62 & 1.00 \\
\hline Reading & Chinese & 0.39 & 0.01 & 0.84 & 0.35 & 1.00 & 0.37 & 0.02 & 0.72 & 0.52 & 1.01 \\
\hline Reading & Caribbean & 0.58 & 0.03 & 0.72 & 0.75 & 1.03 & 0.57 & 0.03 & 0.60 & 0.71 & 1.03 \\
\hline Reading & African & 0.60 & 0.02 & 0.71 & 0.73 & 1.02 & 0.57 & 0.05 & 0.57 & 0.73 & 1.06 \\
\hline
\end{tabular}

Source: 2001/2011 UK Census. Own Elaboration

Figure A1. Dendograms for cluster analysis (Ward connection method)

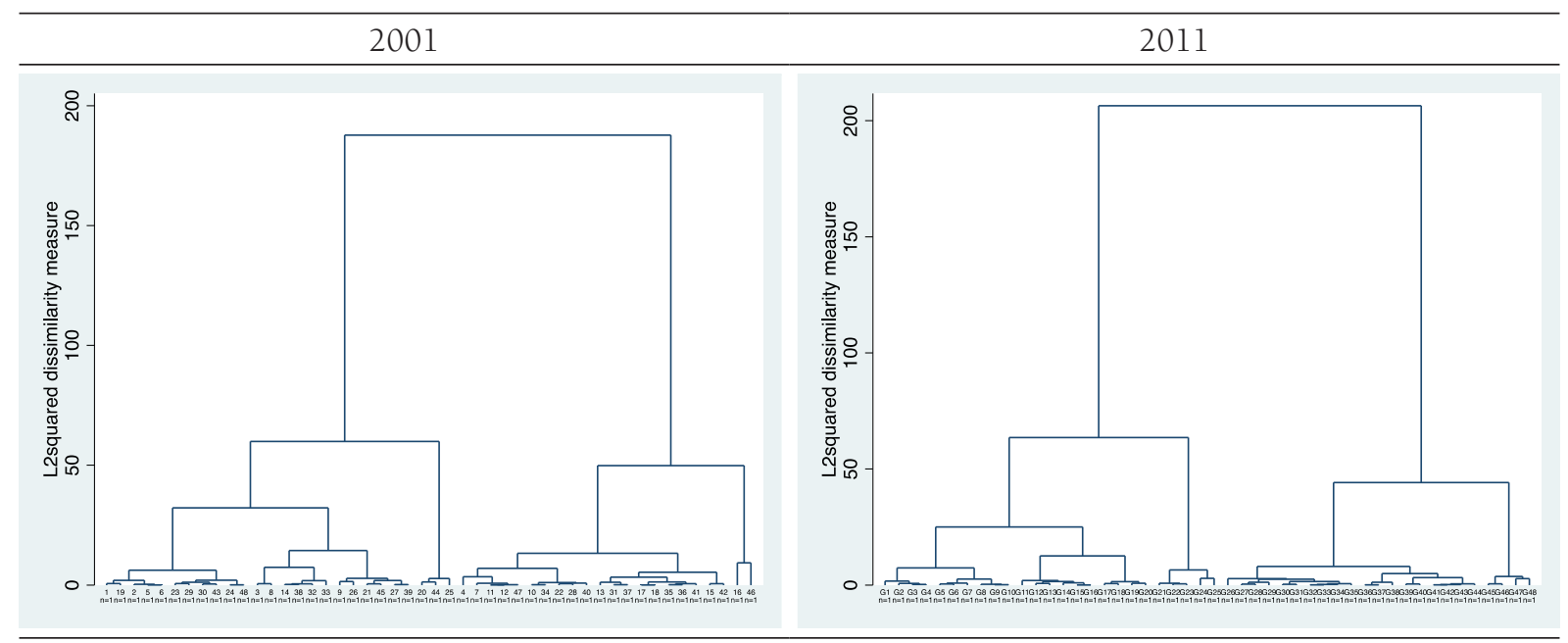

Source: 2001/2011 UK Census. Own Elaboration 
Figure A2. Pakistanis in Bradford HMA (central area) (\%)

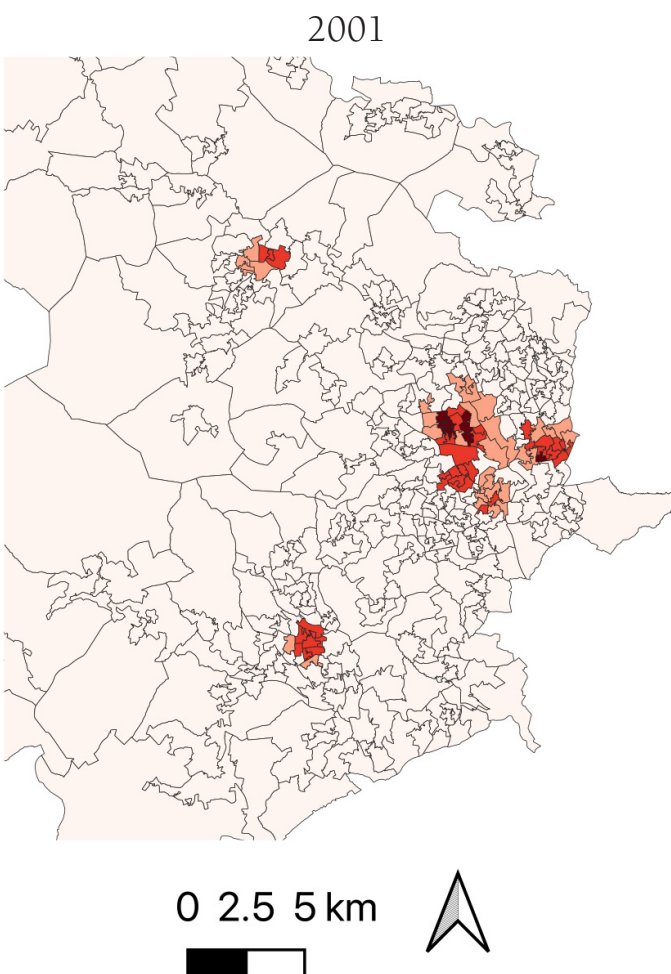

Areas with $50 \%-70 \%=32$

Areas with $70 \%-100 \%=8$
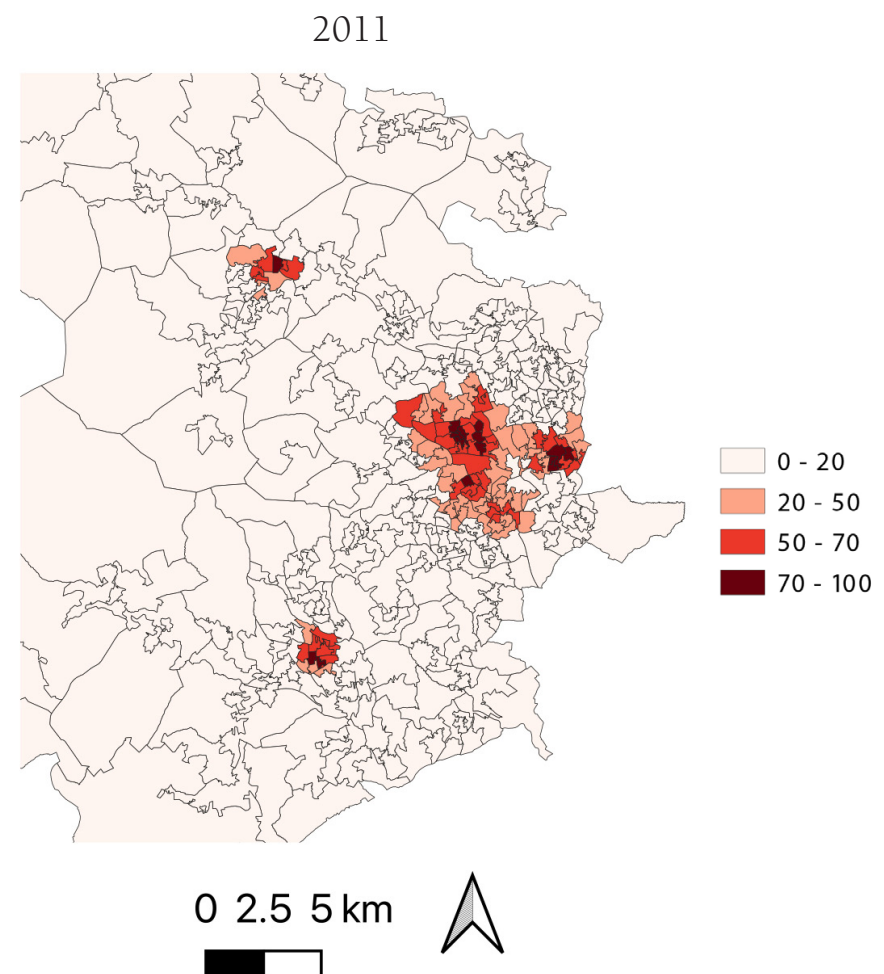

Areas with 50\%-70\%=43

Areas with $70 \%-100 \%=15$

Source: 2001/2011 UK Census. LSOA boundaries. Own Elaboration

Figure A3. Bangladeshis in London HMA (Whitechapel area) (\%)

2001
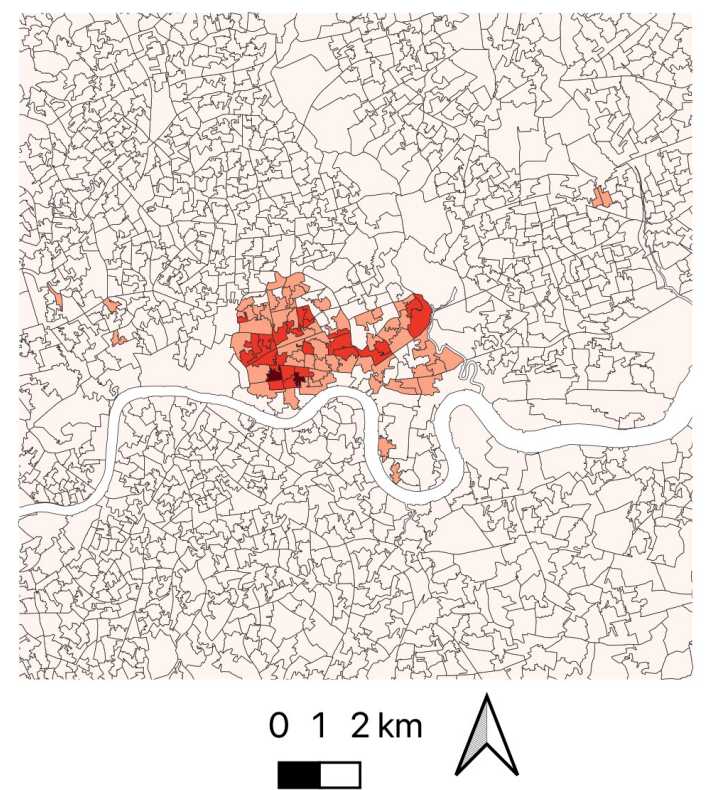

Areas with 50\%-70\%=22

Areas with $70 \%-100 \%=2$
2011

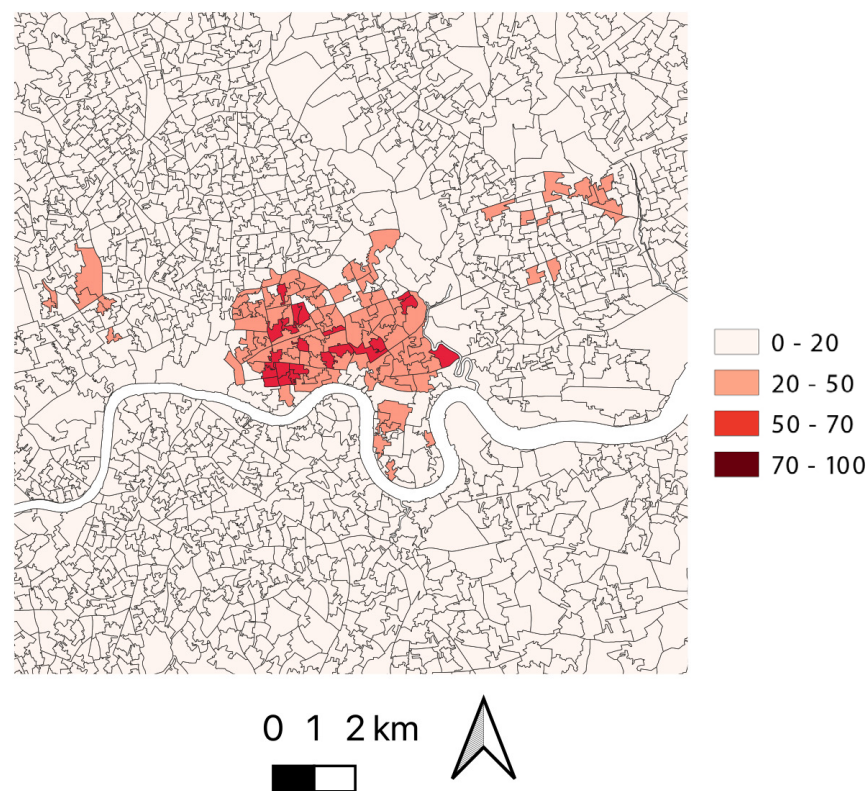

Areas with $50 \%-70 \%=20$

Areas with $70 \%-100 \%=0$

Source: 2001/2011 UK Census. LSOA boundaries. Own Elaboration 


\section{References}

Alba, R., \& Nee, V. (2003). Remaking the American mainstream. Assimilation and contemporary immigration. Cambridge: Harvard University Press. https://doi.org/10.4159/9780674020115

Apparicio, P., Fournier, É., \& Apparicio, D. (2012). Geo-Segregation Analyzer: a multi-platform application (version 1.0). Montreal: Spatial Analysis and Regional Economics Laboratory (SAREL), INRS Urbanisation Culture Société.

Ariza, M., \& Solís, P. (2009). Dinámica socioeconómica y segregación espacial en tres áreas metropolitanas de México, 1990 y 2000. Estudios sociológicos, 27(79), 171-209.

Bagguley, P., \& Hussain, Y. (2019). Ethnic riots in United Kingdom in 2001. In S. Ratuva (Ed.), The Palgrave Handbook of Ethnicity (pp. 1-16). Singapore: Springer Singapore. https://doi.org/10.1007/978981-13-0242-8_30-1

Bowes, A., Dar, N. S., \& Sim, D. F. (2002). Differentiation in housing careers: the case of Pakistanis in the UK. Housing Studies, 17(3), 381-399. https://doi.org/10.1080/02673030220134917

Carling, A. (2008). The curious case of the mis-claimed myth claims: ethnic segregation, polarisation and the future of Bradford. Urban Studies, 45(3), 553-589. https://doi.org/10.1177/0042098007087335

Catney, G. (2013). Has neighbourhood ethnic segregation decreased?. Manchester: Centre on the Dynamics of Ethnicity. Retrieved from http://www.ethnicity.ac.uk/census/885_CCSR_Neighbourhood_Bulletin_ v7.pdf

Catney, G. (2016a). The changing geographies of ethnic diversity in England and Wales, 1991-2011. Population, Space and Place, 22, 750-765. https://doi.org/10.1002/psp.1954

Catney, G. (2016b). Exploring a decade of small area ethnic (de-)segregation in England and Wales. Urban Studies, 53(8), 1691-1709. https://doi.org/10.1177/0042098015576855

Catney, G. (2017). Towards an enhanced understanding of ethnic group geographies using measures of clustering and unevenness. The Geographical Journal, 183(1), 71-83. https://doi.org/10.1111/ geoj. 12162

Catney, G. (2018). The complex geographies of ethnic residential segregation: Using spatial and local measures to explore scale-dependency and spatial relationships. Transactions of the Institute of British Geographers, 43(1), 137-152. https://doi.org/10.1111/tran.12209

Cheung, S. Y., \& Heath, A. (2007). Nice work if you can get it: ethnic penalties in Great Britain. In A. Heath \& S. Y. Cheung (Eds.), Unequal chances. Ethnic minorities in Western labour markets (pp. 507550). New York: Oxford University Press. https://doi.org/10.5871/bacad/9780197263860.003.0012

Coulter, R., \& Clark, W. A. V. (2018). Ethnic disparities in neighbourhood selection: Understanding the role of income. International Journal of Urban and Regional Research, (in press). https://doi. org/10.1111/1468-2427.12697

Crawford, C., \& Greaves, E. (2015). Socio-economic, ethnic and gender differences in HE participation. Retrieved from London:

Dale, A., Fieldhouse, E., Shaheen, N., \& Kalra, V. (2002). The labour market prospects for Pakistani and Bangladeshi women. Work, Employment \& Society, 16(1), 5-25. https://doi. org/10.1177/09500170222119227

Duncan, O. D., \& Duncan, B. (1955). Residential distribution and occupational stratification. American Journal of Sociology, 60(5), 493-503. https://doi.org/10.1086/221609

Finney, N., \& Simpson, L. (2009a). Population dynamics: the roles of natural change and migration in producing the ethnic mosaic. Journal of Ethnic and Migration Studies, 35(9), 1479-1496. https://doi. org/10.1080/13691830903125935

Finney, N., \& Simpson, L. (2009b). 'Sleepwalking to segregation'?: Challenging myths about race and migration. Bristol: The Policy Press. https://doi.org/10.2307/j.ctt9qgrt7

Harris, R., Johnston, R., \& Manley, D. (2017). The changing interaction of ethnic and socioeconomic segregation in England and Wales, 1991-2011. Ethnicities, 17(3), 320-349. https://doi. org/10.1177/1468796815595820 
Heath, A., \& Demireva, N. (2013). Has multiculturalism failed in Britain? Ethnic and Racial Studies, 37(1), 161-180. https://doi.org/10.1080/01419870.2013.808754

Heath, A., \& Martin, J. (2013). Can religious affiliation explain 'ethnic' inequalities in the labour market? Ethnic and Racial Studies, 36(6), 1005-1027. https://doi.org/10.1080/01419870.2012.657660

Iceland, J., Weinberg, D. H., \& Steinmetz, E. (2002). Racial and ethnic residential segregation in the United States: 1980-2000. Washington, DC.: U.S. Census Bureau, Series CENSR-3.

Jargowsky, P. A. (2018). The persistence of segregation in the 21st Century. Law and Inequality: A Journal of Theory and Practice, 36(2), 207-230.

Johnston, R., Jones, K., Manley, D., \& Owen, D. (2016). Macro-scale stability with micro-scale diversity: modelling changing ethnic minority residential segregation - London 2001-2011. Transactions of the Institute of British Geographers, 41(4), 389-402. https://doi.org/10.1111/tran.12142

Johnston, R., Poulsen, M., \& Forrest, J. (2010). Moving on from indices, refocusing on mix: on measuring and understanding ethnic patterns of residential segregation. Journal of Ethnic and Migration Studies, 36(4), 697-706. https://doi.org/10.1080/13691830903505045

Johnston, R., Poulsen, M., \& Forrest, J. (2015). Increasing diversity within increasing diversity: the changing ethnic composition of London's neighbourhoods, 2001-2011. Population, Space and Place, 21(1), 38-53. https://doi.org/10.1002/psp.1838

Jones, C., Coombes, M., \& Wong, C. (2010). Geography of housing market areas: final report. London: Department for Communities and Local Government.

Jones, K., Johnston, R., Manley, D., Owen, D., \& Charlton, C. (2015). Ethnic residential segregation: a multilevel, multigroup, multiscale approach exemplified by London in 2011. Demography, 52(6), 1995-2019. https://doi.org/10.1007/s13524-015-0430-1

Krysan, M., \& Crowder, K. (2017). Cycle of segregation: Social processes and residential stratification. New York: Russel Sage Foundation. https://doi.org/10.7758/9781610448697

Logan, J. R. (2013). The persistence of segregation in the 21st Century metropolis. City E Community, 12(2), 160-168. https://doi.org/10.1111/cico.12021

Massey, D. S. (1985). Ethnic residential segregation: a theoretical synthesis and empirical review. Sociology and social research, 69(3), 315-350.

Massey, D. S., \& Denton, N. A. (1988). The dimensions of residential segregation. Social Forces, 67(2), 281-315. https://doi.org/10.1093/sf/67.2.281

Massey, D. S., \& Tannen, J. (2018). Suburbanization and segregation in the United States: 1970-2010. Ethnic and Racial Studies, 41(9), 1594-1611. https://doi.org/10.1080/01419870.2017.1312010

Müller, T. S., Grund, T. U., \& Koskinen, J. H. (2018). Residential segregation and 'ethnic flight' vs. 'ethnic avoidance' in Sweden. European Sociological Review, 34(3), 268-285. https://doi.org/10.1093/esr/ jcy010

Musterd, S., \& van Kempen, R. (2009). Segregation and housing of minority ethnic groups in Western European cities. Tijdschrift voor economische en sociale geografie, 100(4), 559-566. https://doi. org/10.1111/j.1467-9663.2009.00558.x

Openshaw, S. (1984). The modifiable area unit problem. Norwick: Geo Books.

Panayi, P. (2010). An immigration history of Britain: multicultural racism since 1800. Harlow: Pearson Education Limited.

Parreño Castellano, J. M., \& Domínguez Mujica, J. (2008). Extranjería y diferenciación residencial en Canarias: la perspectiva del microanálisis espacial. Investigaciones Geográficas, (45), 163-199. https:// doi.org/10.14198/INGEO2008.45.07

Peach, C. (2005). Social integration and social mobility: spatial segregation and intermarriage of the Caribbean population in Britain. In G. C. Loury, T. Modood, \& S. M. Teles (Eds.), Ethnicity, social mobility and public policy (pp. 178-203). Cambridge: Cambridge University Press. https://doi. org/10.1017/CBO9780511489228.008

Phillips, D. (1998). Black minority ethnic concentration, segregation and dispersal in Britain. Urban Studies, 35(10), 1681-1702. https://doi.org/10.1080/0042098984105 
Phillips, D. (2006). Parallel lives? Challenging discourses of British Muslim self-segregation. Environment and Planning D: Society and Space, 24(1), 25-40. https://doi.org/10.1068/d60j

Poulsen, M., \& Johnston, R. (2008). The 'new geography' of ethnicity in England and Wales?. In C. Dwyer \& C. Bressey (Eds.), New geographies of race and racism. Aldershot: Ashgate.

Rattansi, A. (2011). Multiculturalism: a very short introduction. Oxford: Oxford University Press. https:// doi.org/10.1093/actrade/9780199546039.001.0001

Schaake, K., Burgers, J., \& Mulder, C. H. (2013). Ethnicity, education and income, and residential mobility between neighbourhoods. Journal of Ethnic and Migration Studies, 40(4), 512-527. https:// doi.org/10.1080/1369183X.2013.830500

Simpson, L. (2007). Ghettos of the mind: the empirical behaviour of indices of segregation and diversity. Journal of the Royal Statistical Society: Series A (Statistics in Society), 170(2), 405-424. https://doi. org/10.1111/j.1467-985X.2007.00465.x

Simpson, L. (2012). More segregation or more mixing?. Manchester: Centre on Dynamics of Ethnicity. Retrieved from http://www.ethnicity.ac.uk/census/869_CCSR_Bulletin_More_segregation_or_more_ mixing_v7NW.pdf

Simpson, L. (2013). What makes ethnic group populations grow? Age structures and immigration. Manchester: Centre on Dynamics of Ethnicity. Retrieved from http://hummedia.manchester.ac.uk/institutes/code/ briefings/dynamicsofdiversity/what-makes-ethnic-group-populations-grow-age-structures-andimmigration.pdf

Simpson, L., \& Finney, N. (2009). Spatial patterns of internal migration: evidence for ethnic groups in Britain. Population, Space and Place, 15(1), 37-56. https://doi.org/10.1002/psp.497

Sørensen, A., Taeuber, K. E., \& Hollingsworth, L. J. (1975). Indexes of Racial Residential Segregation for 109 Cities in the United States, 1940 to 1970. Sociological Focus, 8(2), 125-142. https://doi.org/10.10 $\underline{\text { 80/00380237.1975.10571422 }}$

Sturgis, P., Brunton-Smith, I., Kuha, J., \& Jackson, J. (2014). Ethnic diversity, segregation and the social cohesion of neighbourhoods in London. Ethnic and Racial Studies, 37(8), 1286-1309. https://doi.org $\underline{10.1080 / 01419870.2013 .831932}$

Uslaner, E. (2012). Segregation and mistrust: diversity, isolation and social cohesion. New York: Cambridge University Press. https://doi.org/10.1017/CBO9781139026758

Yang, T.-C., Zhao, Y., \& Song, Q. (2017). Residential segregation and racial disparities in self-rated health: How do dimensions of residential segregation matter? Social Science Research, 61, 29-42. https://doi. org/10.1016/j.ssresearch.2016.06.011

Yao, J., Wong, D. W. S., Bailey, N., \& Minton, J. (2018). Spatial segregation measures: a methodological review. Tijdschrift voor economische en sociale geografie, 0(0). https://doi.org/10.1111/tesg.12305

Zuccotti, C. V. (2019). Ethnicity and neighbourhood attainment in England and Wales: A study of second generations' spatial integration. Population, Space and Place, e2252. https://doi.org/10.1002/psp.2252

Zuccotti, C. V., \& Platt, L. (2017). Does neighbourhood ethnic concentration in early life affect subsequent labour market outcomes? A study across ethnic groups in England and Wales. Population, Space and Place, 23(6), e2041. https://doi.org/10.1002/psp.2041

Zuccotti, C. V., \& Platt, L. (2019). A theoretical discussion and empirical analysis of second generations' education and labour market outcomes in England and Wales. Florence: EUI RSCAS Working Paper 2019/38. https://doi.org/10.2139/ssrn.3401880 